Journal of Thermal Engineering, Vol. 6, No. 1, pp. 141-156, January, 2020

Yildiz Technical University Press, Istanbul, Turkey

\title{
ECONOMIC AND ENVIRONMENTAL IMPACTS OF THERMAL INSULATION USED IN DIFFERENT DUCT SIZES
}

\author{
Dileep Kumar ${ }^{1, *}$, Sanjay Kumar ${ }^{1}$, Bilawal Ahmed Bhayo ${ }^{1}$, Khanji Harijan², Muhammad Aslam Uqali $^{3}$
}

\begin{abstract}
In this study, the economic and environmental impacts of insulation material are determined for different sizes of heating, ventilation and air conditioning (HVAC) duct. The optimum insulation thickness (OIT), energy-saving (ES) and payback period (PP) for HVAC duct are estimated using Life cycle cost (LCC) analysis. The analysis considers coal, natural gas (NG), liquefied petroleum gas (LPG), fuel oil (FO), bagasse, rice husk (RH) and geothermal as an energy source and the fiberglass as an insulation material. The results indicate the OIT and PP for an HVAC duct increase with the size of the duct while ES decreases. The maximum value of OIT, ES and minimum value of PP for different sizes and energy sources are determined as $48.27 \mathrm{~mm}$ in size A (300 mm) and NG, 84.91\% in size E (500 $\mathrm{mm}$ ) and LPG, and 0.2035 years in size A and NG, respectively. Additionally, the environmental analysis results indicate emission of $\mathrm{CO}_{2}, \mathrm{CO}$ and $\mathrm{SO}_{2}$ decreases with insulation thickness. The maximum value of $\mathrm{CO}_{2}$ and $\mathrm{CO}$ emission is determined for size $\mathrm{E}$ and $\mathrm{NG}$ i.e. $81.8 \%$ and $\mathrm{SO}_{2}$ emission for size $\mathrm{E}$ and $\mathrm{FO}$ i.e. $76.66 \%$, respectively.
\end{abstract}

\section{Keywords: Optimum Insulation Thickness, Energy Saving, Life Cycle Cost Analysis, Environmental Analysis}

\section{INTRODUCTION}

Energy consumption (EC) is escalating throughout the globe due to rapid population growth, improvement in living standard and style of human beings, urbanization, and migration towards large cities and development in technologies [1]. In addition to that the scarcity of energy supply, depletion of existing energy resources and environmental annihilation has raised a concern about EC. Therefore, EC is a critical issue of recent research. Suitable energy conservation measures significantly decrease EC [2]. Generally, there are four main sectors of EC i.e. industrial, transportation, building (commercial and residential) and agriculture. The building is responsible for $40 \%$ of the total energy demand of the developed countries [3] and the HVAC system is responsible for 10-20\% to maintain a suitable indoor environment [4]. It results in $40 \%$ of the total greenhouse gas emissions [5]. However, the use of insulation material in buildings and the HVAC system reduces EC significantly. In an HVAC system, energy loss due to improper use of insulation material and thickness on ducting and piping [6]. Therefore, the use of insulation in an HVAC system not only reduces its EC but also abates emission products.

Mostly engineering investigations consider insulation material and thickness as an important parameter for economic and environmental savings. The economic insulation thickness concept is based on net saving obtained using insulation cost and energy cost for the HVAC system over the expected lifetime. The OIT for HVAC pipe or duct is determined using design, operating and economical parameters [7].

The degree-time concept is one of the simplest methods used to determine the cooling/heating energy requirement of a building under constant operating and environmental conditions. Zaki and Al-Turki [8] determined OIT for the pipelines of oil industry using LCC analysis. They considered superheated steam, furfural, crude oil, and 300-distillate as a working fluid and Rockwool and calcium silicate as an insulation material. The results indicate net saving increases with pipe size. Li and Chow [9] determined OIT for different size pipes to protect them from cold freezing using LCC analysis. The results reveal that insulation thickness decreases with insulation's thermal conductivity and cost, while it increases with insulated pipe exterior surface temperature. Soponpongpipat et al. [10] estimated the OIT for HVAC duct using thermo-economic analysis. They considered galvanized steel duct $(0.5 \mathrm{~m})$ with

This paper was recommended for publication in revised form by Regional Editor Hafiz Muhammad Ali

${ }^{1}$ Department of Mechanical Engineering, Mehran University of Engineering \& Technology, SZAB, Campus, Khairpur Mir's, Pakistan

${ }^{2}$ Department of Mechanical Engineering, Mehran University of Engineering \& Technology, Jamshoro, Pakistan

${ }^{3}$ Department of Electrical Engineering, Mehran University of Engineering \& Technology, Jamshoro, Pakistan

*E-mail address:dileepkumar@muetkhp.edu.pk

Orcid id: 0000-0001-5139-0174, 0000-0003-0139-3179, 0000-0001-7146-1275, 0000-0002-8624-6145, 0000-0002-2228-4687

Manuscript Received 26 January 2018, Accepted 07 April 2018 
glass wool and rubber as insulation material for their analysis. The results show that OIT remains constant with a convective heat transfer coefficient, contrary to ES increases. Keçebas et al. [11] estimated that the maximum ES is achieved for pipe (250 mm) and FO, whereas its lower value is determined for pipe (50 mm) and geothermal energy. Additionally, they investigated that the use of geothermal energy for chiller/boiler operation produces both environmental and economic benefits. His other study [12] investigates the effect of fuel inlet, stack gas and combustion chamber temperature and air-fuel ratio on OIT, ES and PP for different pipe sizes using energoeconomic and exergoeconomic method. The results indicate that OIT calculated using energoeconomic method was greater than exergoeconomic method. The effect of wind speed on OIT, ES, and PP for HVAC's duct installed outside the building is estimated using LCC analysis in the city of Usak, Turkey. The analysis considers LPG, NG, FO, and Coal as an energy source and Rockwool and fiberglass as insulation. The results show that the ES increases with wind speed for HVAC's duct [13].

The above literature shows that significant research has been conducted to determine OIT, ES, and PP for pipelines installed in industries, refineries, and the HVAC system. In contrast, fewer studies are conducted for HVAC's duct. Consequently, less attention is given towards the environmental impacts of energy loss through HVAC's duct and piping. On the other hand, significant research has been conducted to investigate the environmental impacts of insulation used in building wall. Comakli and Yüksel [14] estimated 12.13\$/m2 net energy saving and 50\% reduction in $\mathrm{CO} 2$ emission for building wall over a lifetime of 10 years in city of Kutahya, Turkey. Dombayc1 [15] estimated the environmental impacts of OIT for the exterior building wall. The analysis considered coal as a fuel and expanded polystyrene as an insulation material. He estimated that OIT reduces fuel consumption and the CO2 and SO2 emission by 46 and 41\%. Yildiz et al. [16] estimated that OIT reduces CO2 emission by 30\% for the insulated wall with glass wool insulation and NG, FO, coal, and LPG as a fuel. Basogul and Keçebas [17] determined the environmental impacts of OIT for district heating pipelines. The results indicate a $21 \%$ reduction in $\mathrm{CO} 2$ emission. Abdullah and Karameldin [18] estimated that OIT for steam piping $(0.225-0.235 \mathrm{~m})$ reduces CO2 form 37.7-26.8 tones/m/year and SO2 from 72 $59 \mathrm{~kg} / \mathrm{m}$-year.

In this study, the OIT, ES, PP, annual fuel consumption and emissions of $\mathrm{CO} 2, \mathrm{CO}$, and $\mathrm{SO} 2$ for the insulated duct is determined in terms of LCC analysis. The analysis considers fiberglass as insulation material and coal, NG, LPG, FO, RH, bagasse and geothermal as an energy source. The heat conductivity and price of the insulation material, average temperature and relative humidity of conditioned air, fuel price are constant in the analysis. The results drawn from the analysis are evaluated.

\section{SELECTED AIR DISTRIBUTION SYSTEM}

The schematic view of the air distribution system for the HVAC system under study is illustrated in Fig. 1. The energy required for the chiller operation is obtained from a boiler, in which fuel sources are commonly oxidized to produce thermal energy. As for the heating coil, the supply air is directly conditioned via heat transfer between supply air and hot water. The heating coil is intended to control the relative humidity of the supply air required for the pharmaceutical zone. In the HVAC system, the conditioned air is supplied to the zone through HVAC ducts. HVAC ducts are usually made out of the galvanized steel, stainless steel and aluminum, and flexible non-metallic materials. Typical HVAC ducts are located outdoor environment, basement floors, attics, garages. There is a significant amount of energy loss occurs in an HVAC duct due to temperature difference between conditioned air and ambient air. Therefore, it is essential to insulate HVAC ducts in terms of energy-saving using different insulation materials.

The design and operating parameters of the air distribution system are obtained from GSK Pharma Pvt. Ltd. are given in Tables $1 \& 2$. The value of density, specific heat, kinematic viscosity, Prandtl number and thermal conductivity of conditioned air inside the duct are obtained by using the appropriate mean value of operating parameters.

\section{ANALYSIS OF AIR DISTRIBUTION SYSTEM}

A life cycle cost analysis considers the net saving resulting from a reduction in energy cost due to a decrease in fuel consumption with added insulation cost over the lifetime of an HVAC system. In building, the LCC analysis is 
usually used to calculate the OIT considering the effect of inflation and interest rate, maintenance cost, salvage value, operating hours, and heating value of fuel and cost of fuel and insulation material [23].

The following assumptions are considered in the analysis:

1. Steady-state conditions are considered.

2. Uniform heat gain occurs throughout the duct.

3. The unit length of the duct is considered.

4. The working fluid and ambient air temperature and relative humidity are constant.

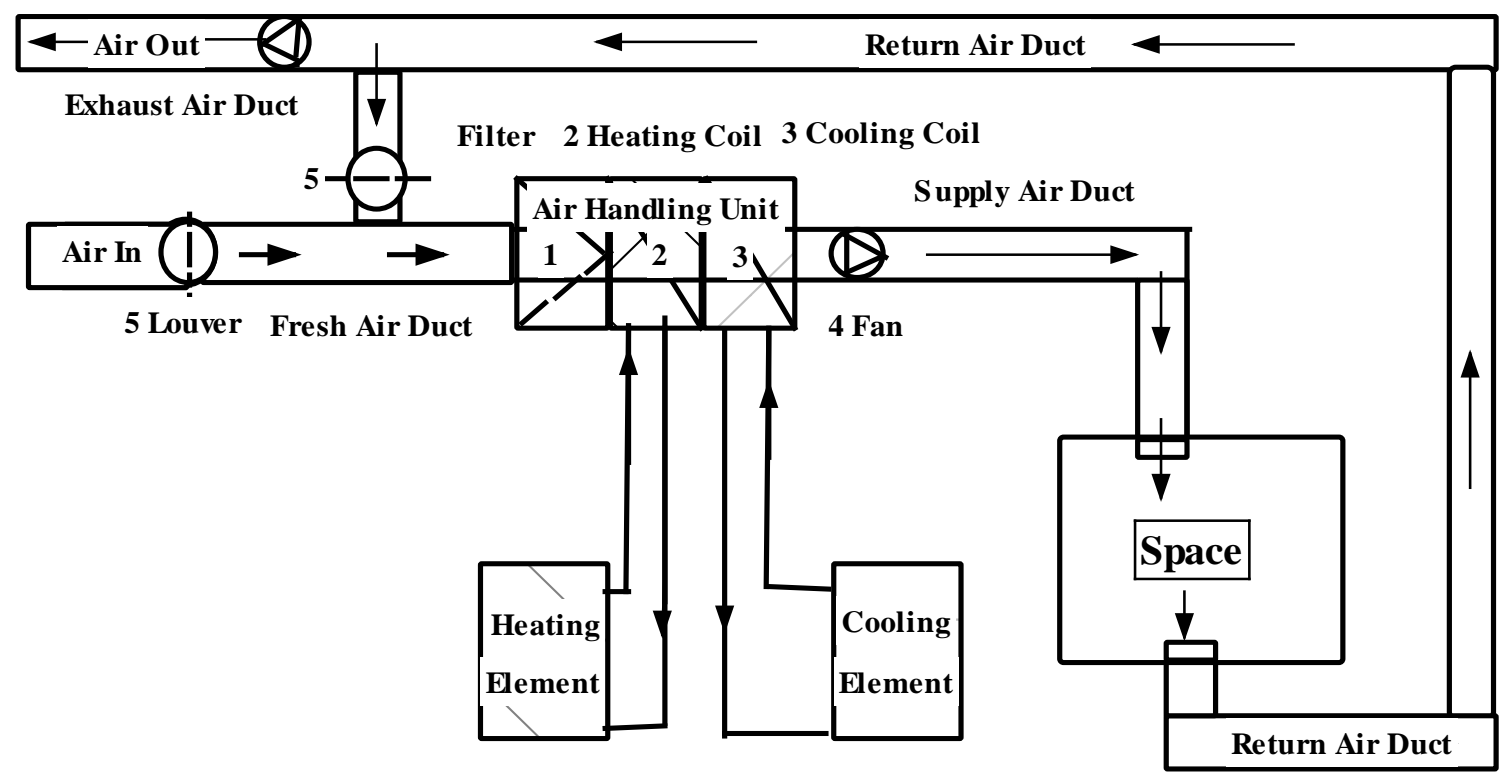

Figure 1. Schematic layout of simple air-distribution system

Table 1. The duct and insulation material properties [10, 13, 19]

\begin{tabular}{|c|c|c|}
\hline & Insulation & Properties \\
\hline Insulation & Fiberglass & $\mathrm{K}_{\text {ins }}=0.037 \mathrm{~W} / \mathrm{m} . \mathrm{K}$ and $\mathrm{C}_{\text {ins }}=352 \mathrm{USD} / \mathrm{m}^{3}$ \\
\hline Duct & Galvanized Steel & $\mathrm{K}_{\mathrm{d}}=60.5 \mathrm{~W} / \mathrm{m} . \mathrm{K}, \quad 300 \leq \mathrm{d}_{\mathrm{d}} \leq 500 \mathrm{~mm}$ and $\quad 0.7 \leq \mathrm{t}_{\mathrm{d}} \leq 1.006 \mathrm{~mm}$ \\
\hline
\end{tabular}

Table 2. Operating parameters [13, 20-22]

\begin{tabular}{|c|c|}
\hline Parameters & Value \\
\hline Supply air in duct & $\mathrm{T}_{\mathrm{i}}=293 \mathrm{~K}, \mathrm{P}_{\mathrm{i}}=1 \mathrm{kPa}(\mathrm{g}) \mathrm{V}_{\mathrm{i}}=10 \mathrm{~m} / \mathrm{s}$ \\
\hline Ambient conditions & $\mathrm{T}_{\mathrm{i}}=303 \mathrm{~K}, \mathrm{~V}_{\mathrm{o}}=4.2 \mathrm{~m} / \mathrm{s}$ and $\mathrm{h}_{\mathrm{o}}=10 \mathrm{~W} / \mathrm{m}^{2} \mathrm{~K}$ \\
\hline CDD & $2384\left({ }^{\circ} \mathrm{C}\right.$-days $)$ \\
\hline Interest Rate & $5 \%$ \\
\hline Inflation Rate & $7 \%$ \\
\hline Lifetime & 15 years \\
\hline
\end{tabular}

The heat gain and insulation economy for an air distribution system

The annual cooling loss through the HVAC duct due to heat gain from the surrounding is determined on the basis of the degree-days method [13].

$$
\dot{Q}_{i n}=\frac{86400 \cdot C D D}{R}
$$

where, $\mathrm{R}$ is the overall heat transfer coefficient of duct layers [13]. It is calculated by Eq. ( 2 \& 3) for bared and insulated duct as shown in Fig. 2 and CDD is the cooling degree days of the city analyzed: 


$$
\begin{gathered}
\frac{1}{R_{u n-i n s}}=\frac{1}{A_{i} \cdot h_{i}}+\frac{\ln \left(\frac{r_{1}}{r_{i}}\right)}{2 \pi \cdot L_{d} \cdot k_{d}}+\frac{1}{A_{o} \cdot h_{o}} \\
\frac{1}{R_{\text {ins }}}=\frac{1}{A_{i} \cdot h_{i}}+\frac{\ln \left(\frac{r_{1}}{r_{i}}\right)}{2 \pi \cdot L_{d} \cdot k_{d}}+\frac{\ln \left(\frac{r_{o}}{r_{2}}\right)}{2 \pi \cdot L_{d} \cdot k_{\text {ins }}}+\frac{1}{A_{o} \cdot h_{o}}
\end{gathered}
$$

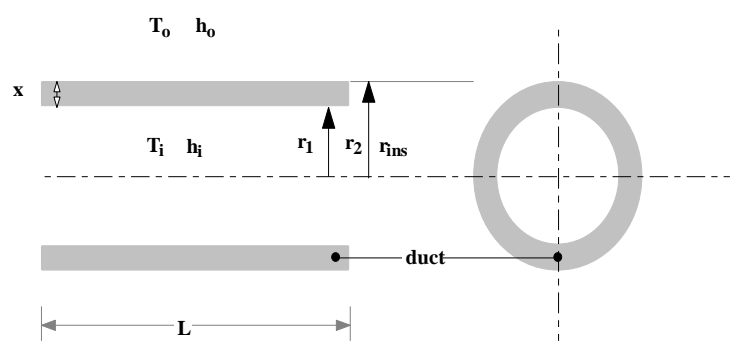

(a)

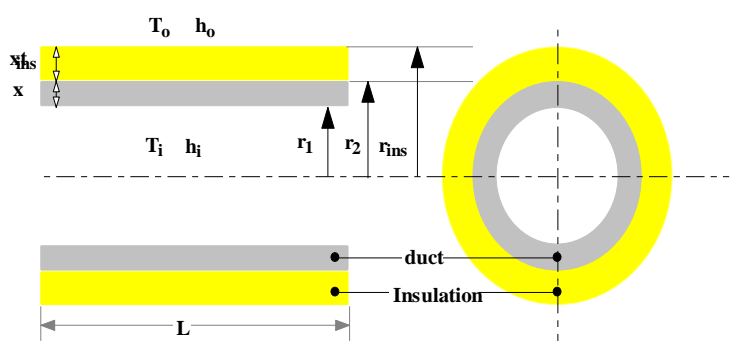

(b)

Figure 2. (a) A bared and (b) insulated duct

Figure 2 exhibits a bared and insulated duct. It represents the dimension of an HVAC duct. L is the length of the duct, $\mathbf{r}_{1}$ and $\mathbf{r}_{2}$ are interior and exterior radius of the duct $\left(\mathbf{r}_{2}=\mathbf{r}_{1}+\mathbf{t}_{\mathbf{d}}\right), \mathrm{r}_{0}$ is the exterior radius of an insulated duct, $A_{1}$ and $A_{2}$ are the interior and exterior surface area of the duct, $A_{0}$ is the exterior surface area of an insulated duct. The $\mathbf{h}_{\mathbf{i}}$ and $\mathbf{h}_{\mathbf{o}}$ are convective heat transfer coefficient of conditioned air and the surrounding air.

The convective heat transfer of conditioned air is calculated as

$$
h_{i}=\frac{\boldsymbol{\kappa}_{a i r} N u}{D_{H}}
$$

where $\kappa_{-}$air is thermal conductivity of conditioned air, DH is a hydraulic diameter of the duct which is calculated by Eq. (5) [24] and Nusselt number (Nu) is calculated by Eq. ( 7 \& 8) laminar and turbulent [25, 26].

$$
D_{h}=\frac{4 A_{c}}{p}
$$

where, $\mathrm{A}_{\mathrm{c}}$ is the cross-sectional area and $\mathrm{P}$ is the perimeter of the duct, respectively. Reynolds Number of air flowing inside the duct is estimated as:

$$
R e=\frac{U D_{H}}{\vartheta}
$$

where, $\mathrm{U}$ and $\vartheta$ are the velocity and kinematic viscosity of the conditioned air.

If $\operatorname{Re} \leq 2800$ and $\operatorname{Pr} \leq 0.7$ then flow through duct will be laminar then:

$$
N u=3.66+\frac{0.66\left(D_{h} / L\right) \operatorname{Re} P r}{1+0.4\left(\left(D_{h} / L\right) \operatorname{Re} P r\right)^{2 / 3}}
$$

If $3 \times 10^{3}<\operatorname{Re}<5 \times 10^{6}$ and $0.5 \leq \operatorname{Pr} \leq 2000$ then flow through duct will be turbulent then 


$$
N u=\frac{f(R e-1000) P r}{8\left(1+12.7\left(\operatorname{Pr}^{2 / 3}-1\right) \sqrt{\frac{f}{8}}\right.}
$$

where $\mathrm{f}$ is the friction factor of inside duct surface, it is calculated by Eq. (8) and Pr is Prandtl number of conditioned air inside the duct:

$$
\frac{1}{\sqrt{f}}=-2.0 \log \left(\frac{\varepsilon}{3.7 D_{H}}+\frac{1}{\operatorname{Re} \sqrt{f}}\right)
$$

where $\varepsilon$ is the relative roughness of duct surface and is calculated as:

$$
\varepsilon=\left(\frac{1.5 \times 10^{-4}}{D_{H}}\right)
$$

The annual fuel consumption is calculated as:

$$
\dot{m}_{F}=\left(\frac{\dot{Q}}{L H V C O P}\right)
$$

where $\dot{m}$ is annual fuel consumption, LHV is lower heating value of energy source and $\eta$ is efficiency of an HVAC system. The annual fuel cost $\left(\mathrm{C}_{\mathrm{F}}\right)$ is calculated as:

$$
C_{F}=\dot{m}_{f} C_{f}
$$

where $\mathrm{Cf}$ is fuel cost. Total initial investment on thermal insulation is calculated as:

$$
C_{\text {ins }}=c_{\text {ins }} Z_{\text {ins }}
$$

where $\mathrm{C}_{\text {ins }}$ is thermal insulation cost and $\mathrm{Z}_{\mathrm{ins}}=\mathrm{At}_{\mathrm{ins}}$ is the quantity of insulation material.

It is possible to calculate the present worth of the net energy saving with an increment in initial investment by the $\mathrm{P}_{1}-\mathrm{P}_{2}$ method. $\mathrm{P}_{1}$ is the ratio life cycle energy cost to initial investment over an expected lifetime. $\mathrm{P}_{2}$ is the ratio of increase in capital investment during the life cycle of the HVAC system to the initial investment. The $\mathrm{P}_{1}$ and $\mathrm{P}_{2}$ are calculated by Eq. (13\&14)

$$
\begin{aligned}
& P_{1}=\left(\frac{1}{d-e}\right)\left(1-\left(\frac{1+e}{1+d}\right)^{N}\right) \text { if } i \neq d \\
& P_{2}=1+P_{1}(M)-(S V)(1+d)^{-N}
\end{aligned}
$$

where $\mathrm{M}$ and SV are the ratio of annual maintenance and the salvage value to initial investment, $\mathrm{d}$ and e represent inflation and interest rate and $\mathrm{N}$ denotes lifetime. The value of P2 will be equal to P1 if operation and maintenance cost is zero $[10,13,19,23,27,28]$. The total life cycle cost of cooling loss is calculated as:

$$
C_{1}=P_{1} C_{F}+P_{2} C_{\text {ins }}
$$


Journal of Thermal Engineering, Research Article, Vol. 6, No. 1, pp. 141-156, January, 2020

Energy-saving (\%) is achieved during the lifetime of the HVAC system will be calculated as [13]:

$$
E S=\left(\frac{C_{2}-C_{1}}{C_{1}}\right) \cdot 100
$$

where $\mathrm{C}_{1}$ and $\mathrm{C}_{2}$ is total life cycle cost incurred on a bared and insulated duct. The payback period (PP) of increment in initial investment is calculated as [13]:

$$
\frac{C_{1}}{C_{2}-C_{1}}=\frac{1}{d-i}\left(1-\left(\frac{1+i}{1+d}\right)^{P P}\right)
$$

\section{Calculation of the annual emission gases amount}

Heat transmission losses through the HVAC duct are reduced by using appropriate insulation material and thickness. This will reduce the annual fuel consumption of an HVAC system. It reduces emission products. The chemical composition of fuel types and their properties along with cost are given in Table 3.

Table 3: Price, lower heating value (LHV) and chemical formulas of fuels and efficiency of cooling system [29-40]

\begin{tabular}{|c|c|c|c|c|c|c|}
\hline Fuels & $\begin{array}{c}\text { Price } \\
\mathbf{( \$ / k g )}\end{array}$ & $\begin{array}{c}\text { LHV } \\
\mathbf{( J / k g )}\end{array}$ & $\begin{array}{c}\boldsymbol{\eta} \\
(\mathbf{\%})\end{array}$ & $\begin{array}{c}\text { COP } \\
(-)\end{array}$ & $\begin{array}{c}\boldsymbol{\beta} \\
\mathbf{( \% )}\end{array}$ & Chemical Formula \\
\hline Natural gas & 0.26 & $50.53 \times 10^{6}$ & 93 & 4.5 & 10 & $\mathrm{C}_{1.05} \mathrm{H}_{4} \mathrm{O}_{0.034} \mathrm{~N}_{0.02}$ \\
\hline LPG & 0.89 & $46.40 \times 10^{6}$ & 92 & 3.0 & 15 & $\mathrm{C}_{3.7} \mathrm{H}_{4.1}$ \\
\hline Fuel Oil & 0.36 & $41.28 \times 10^{6}$ & 80 & 2.1 & 20 & $\mathrm{C}_{7.3125} \mathrm{H}_{10.407} \mathrm{O}_{0.04} \mathrm{~S}_{0.026} \mathrm{~N}_{0.02}$ \\
\hline Coal & 0.10 & $29.26 \times 10^{6}$ & 65 & 2.4 & 30 & $\mathrm{C}_{7.078} \mathrm{H}_{5.149} \mathrm{O}_{0.517} \mathrm{~S}_{0.01} \mathrm{~N}_{0.086}$ \\
\hline Bagasse & 0.03 & $9.73 \times 10^{6}$ & 76 & 2.2 & 30 & $\mathrm{C}_{4} \mathrm{H}_{6.44} \mathrm{O}_{2.81}$ \\
\hline Rice Husk & 0.08 & $14.50 \times 10^{6}$ & 68 & 2.5 & 30 & $\mathrm{C}_{3.75} \mathrm{H}_{5.74} \mathrm{O}_{2.98} \mathrm{~S}_{0.0063} \mathrm{~N}_{0.043}$ \\
\hline Geothermal & 0.50 & $80.98 \times 10^{6}$ & 38 & 3.2 & - & - \\
\hline
\end{tabular}

The general chemical formula of combustion for fuel is calculated by [17]:

$$
\mathrm{C}_{c} \mathrm{HO}_{o} \mathrm{~N}_{n} \mathrm{~S}_{s}+\beta \alpha_{\text {min }}\left(\mathrm{O}_{2}+3.762 \mathrm{~N}_{2}\right) \rightarrow c_{1} \mathrm{CO}_{2}+c_{2} \mathrm{CO}+\frac{\mathrm{h}}{2} \mathrm{H}_{2} \mathrm{O}+\mathrm{s} \mathrm{SO}_{2}+\mathrm{n}_{1} \mathrm{NO}_{2}
$$

where $\alpha_{\min }, \mathrm{c}_{1}, \mathrm{c}_{2}$ and $\mathrm{n}_{1}$ are estimated from the oxygen balance formulas given in Eq. 20-23, respectively:

$$
\begin{gathered}
\alpha_{\text {min }}=c_{1}+\frac{h}{4}+s+\frac{o}{2} \\
c_{1}=c+c_{2} \\
\beta \alpha_{\text {min }}=c_{1}+c_{2}+\frac{h}{4}+s+\frac{o}{2} \\
n_{1}=3.762 \beta \alpha_{\text {min }}+n
\end{gathered}
$$

The emission rate of combustion products per $1 \mathrm{~kg}$ of fuel burned can be calculated by

$$
\begin{gathered}
\mathrm{M}_{\mathrm{CO} 2}=\frac{\mathrm{c}_{1} \mathrm{CO}_{2}}{\mathrm{M}}=\mathrm{kg} \text { of } \frac{\mathrm{CO} 2}{\mathrm{~kg}} \text { of fuel } \\
\mathrm{M}_{\mathrm{CO}}=\frac{\mathrm{c}_{2} \mathrm{CO}}{\mathrm{M}}=\mathrm{kg} \text { of } \frac{\mathrm{CO}}{\mathrm{kg}} \text { of fuel }
\end{gathered}
$$


Journal of Thermal Engineering, Research Article, Vol. 6, No. 1, pp. 141-156, January, 2020

$$
\begin{aligned}
& \mathrm{M}_{S O 2}=\mathrm{c}_{1} \mathrm{SO}_{2} / \mathrm{M}=\mathrm{kg} \text { of } \mathrm{SO}_{2} / \mathrm{kg} \text { of fuel } \\
& \mathrm{M}_{\mathrm{H} 2 \mathrm{O}}=\mathrm{c}_{1} \mathrm{H}_{2} \mathrm{O} / \mathrm{M}=\mathrm{kg} \text { of } \mathrm{H}_{2} \mathrm{O} / \mathrm{kg} \text { of fuel }
\end{aligned}
$$

where $\mathrm{M}$ denotes the molecular weight of the fuel and it is estimated by Eq. 28

$$
\begin{gathered}
\mathrm{M}=12 \mathrm{c}+\mathrm{h}+16 \mathrm{o}+14 \mathrm{n}+32 \mathrm{~s} \\
\mathrm{M}_{C O}=\mathrm{c}_{2} \mathrm{CO} / \mathrm{M}=\mathrm{kg} \text { of } \mathrm{CO} / \mathrm{kg} \text { of fuel } \\
\mathrm{M}_{\mathrm{SO} 2}=\mathrm{c}_{1} \mathrm{SO}_{2} / \mathrm{M}=\mathrm{kg} \text { of } \mathrm{SO}_{2} / \mathrm{kg} \text { of fuel } \\
\mathrm{M}_{\mathrm{H} 2 \mathrm{O}}=\mathrm{c}_{1} \mathrm{H}_{2} \mathrm{O} / \mathrm{M}=\mathrm{kg} \text { of } \mathrm{H}_{2} \mathrm{O} / \mathrm{kg} \text { of fuel }
\end{gathered}
$$

The total emission of $\mathrm{CO} 2, \mathrm{CO}, \mathrm{SO} 2$, and $\mathrm{H} 2 \mathrm{O}$ can be calculated using the fuel consumption mf (from Eq. (11)), which is total burned fuel within CDD. The equations of emission are given in

$$
\begin{gathered}
\mathrm{M}_{C O}=\left(\frac{28 \mathrm{c}_{2}}{\mathrm{M}}\right) \dot{\mathrm{m}}_{f} \\
\mathrm{M}_{C O 2}=\left(44 \mathrm{c}_{1} / \mathrm{M}\right) \dot{\mathrm{m}}_{f} \\
\mathrm{M}_{S O 2}=(44 \mathrm{~s} / \mathrm{M}) \dot{\mathrm{m}}_{f}
\end{gathered}
$$

\section{RESULTS AND DISCUSSION}

This study estimates the economic and environmental impacts of the insulation used in an HVAC duct installed outside the building in the city of Jamshoro, Pakistan. Using LCC analysis, OIT, ES and PP for different duct sizes are estimated. The analysis considers the design, operating, economic and environmental parameters given in Table 1, 2 and 3. Additionally, the environmental impacts of OIT for different duct sizes are determined using various energy sources.

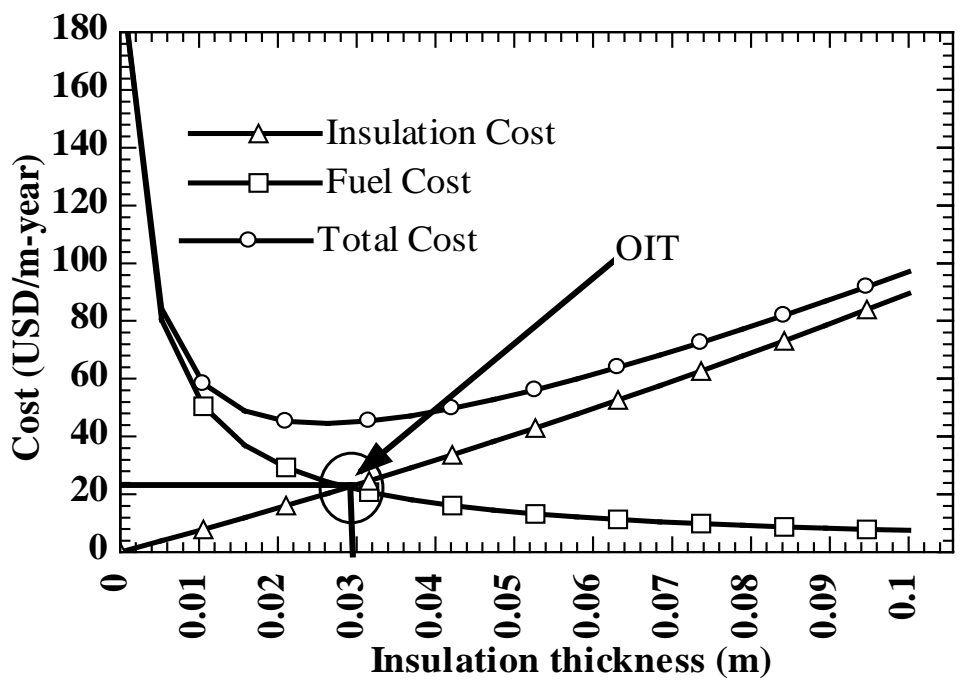

Figure 3. Total cost verses insulation thickness 
The effects of insulation thickness on total cost, insulation cost and fuel cost over a lifetime of HVAC system is illustrated in Fig. 3. The fuel cost is inversely proportional to insulation thickness because insulation thickness over the duct reduces energy loss. Moreover, the parabolic relationship occurs between insulation thickness and cost because insulation quantity increases radially with its thickness on the duct. The total cost is the sum of fuel and insulation cost. Therefore, total cost decreases with insulation thickness up to OIT then it increases. The insulation thickness at which total cost is determined is known as OIT and it is equal to $30 \mathrm{~mm}$ as shown in Fig. 3. The results indicate the highest value of OIT for the duct in case NG and its lowest value in case of bagasse. The OIT for different duct sizes varies between 36.52-48.27mm for NG, 36.38-42.70mm for LPG, 18.65-24.15mm for coal, 28.79-34.64mm for FO, 16.35$17.29 \mathrm{~mm}$ for bagasse, $20.07-21.72 \mathrm{~mm}$ for $\mathrm{RH}, 32.44-37.16 \mathrm{~mm}$ for geothermal, respectively. The maximum value of total cost for different duct sizes under various fuel types varies between 11.93-34.98USD/m-year for NG, 10.8837.52USD/m-year for FO, 11.88-54.51USD/m-year for LPG, 6.83-22.4USD/m-year for coal, 7.67-18.72USD/m-year for geothermal, 4.49-8.91USD/m-year for bagasse and 6.79-17.19USD/m-year for RH, respectively.
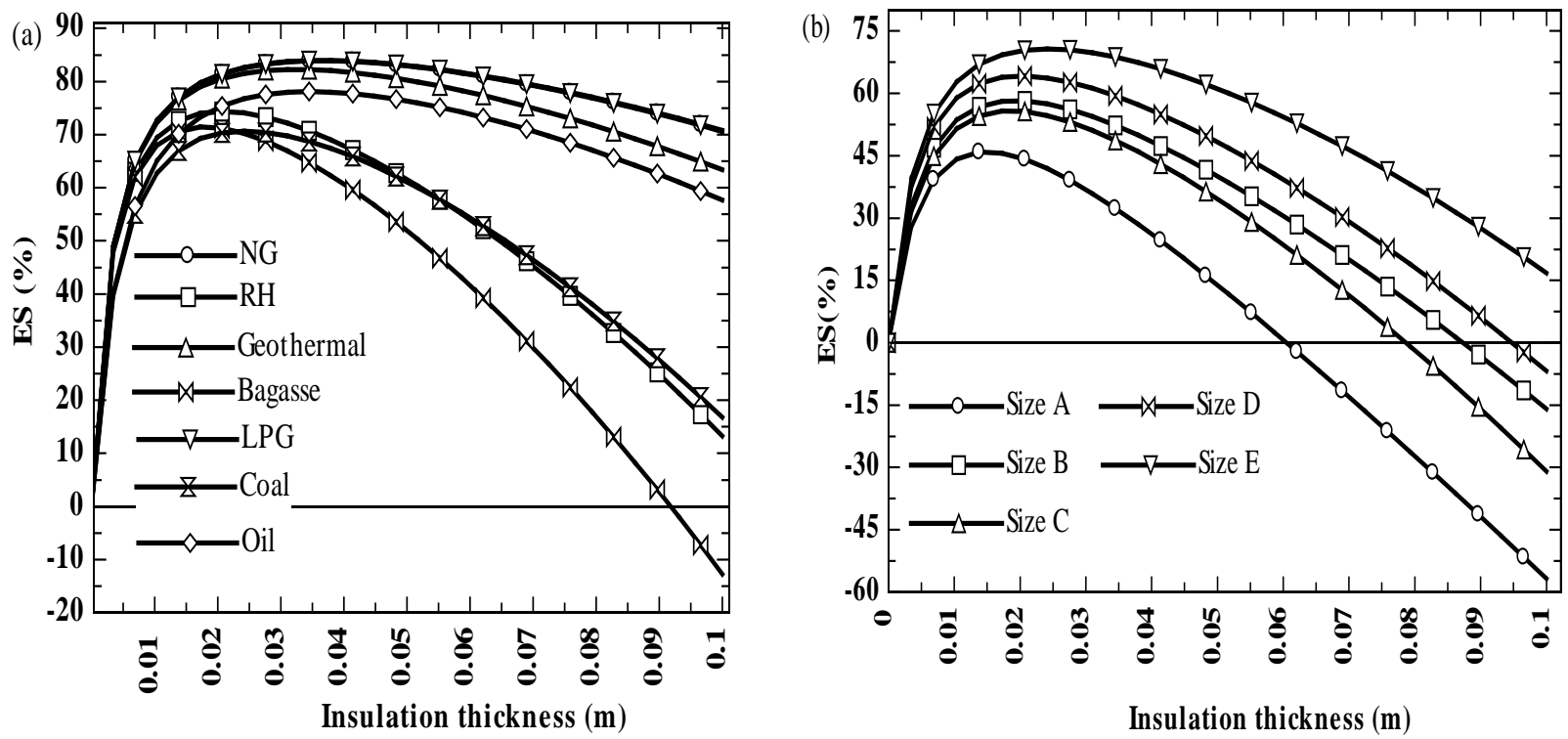

Figure 4. ES V/S insulation thickness for HVAC duct considering different (a) energy source in size E and (b) sizes in case of NG

The effects of insulation thickness on ES in duct size E under different energy sources are illustrated in Fig. 4. The energy-saving in duct size E increases with insulation thickness up to OIT. Once OIT is achieved further increment in insulation thickness reduces ES. Therefore, an additional increment in insulation thickness would be no longer be economical. The ES varies between $74.01-83.95 \%$ for NG, $74.02-83.91 \%$ for LPG, $54.17-70.67 \%$ for coal, 66.44-78.09\% for FO, 50.25-70.49\% for bagasse, $56.92-74.38 \%$ for RH, $71.03-82.87 \%$ for geothermal, respectively. The highest value of the ES is estimated for NG and LPG, whereas the lowest for bagasse. Fig. 4b shows the effects of insulation thickness in different duct sizes in the case of NG. The maximum ES occurs in Size E whereas lower value in size A. The maximum value of ES at OIT in different duct sizes for various energy sources is given in Table 4. The OIT is estimated by minimizing the Eq. 16. The outside radius of the insulated HVAC's duct is calculated using OIT and exterior radius of the duct. Total cost is differentiated with respect to $r_{o}$ and equate to zero. The OIT is calculated $\left(\mathrm{t}_{\mathrm{opt}}=\mathrm{r}_{\text {ins }}-\mathrm{r}_{\mathrm{o}}\right)$ using the EES optimization toolbox.

The variation in PP with insulation thickness for duct size E under different energy sources is illustrated in Fig. 5a. The PP of initial investment cost occurs in duct size E decreases with insulation thickness up to OIT. Once OIT is achieved further increment in insulation thickness increases the PP. It is economically fruitless because it delays the recovery of the initial investment. The results show that the PP of initial investment for the duct size E at OIT is 
different for various energy sources. The higher value of PP corresponding to OIT is determined for bagasse and coal, whereas the lower value for NG and LPG. Other energy sources have intermediate values. Moreover, the effect of insulation thickness on PP for different duct sizes is illustrated in Fig. 5b for NG. A similar trend of variation in PP is determined for different duct sizes as shown in Fig. 5a. The higher value of PP corresponding to OIT is achieved for size A because it has higher initial investment cost and lowers fuel saving. Therefore, the lower value of PP for different duct sizes is obtained for size E. The PP for different duct sizes decrease with the size of the duct.

The OIT, ES, and PP for different duct sizes at various fuels are given in Table 4. The OIT, ES, and PP vary between 16.35-48.27mm, 52.06-83.95\%, and 0.204-1.005years, respectively. The higher ES in different duct sizes are obtained for NG, LPG and geothermal, whereas the lower ES is investigated for bagasse and coal and intermediate value of ES is obtained for RH and FO. The minimum value of PP for different duct sizes is obtained for NG, LPG and geothermal, its intermediate value is obtained for RH and FO, whereas, it's higher value is obtained for bagasse and coal.
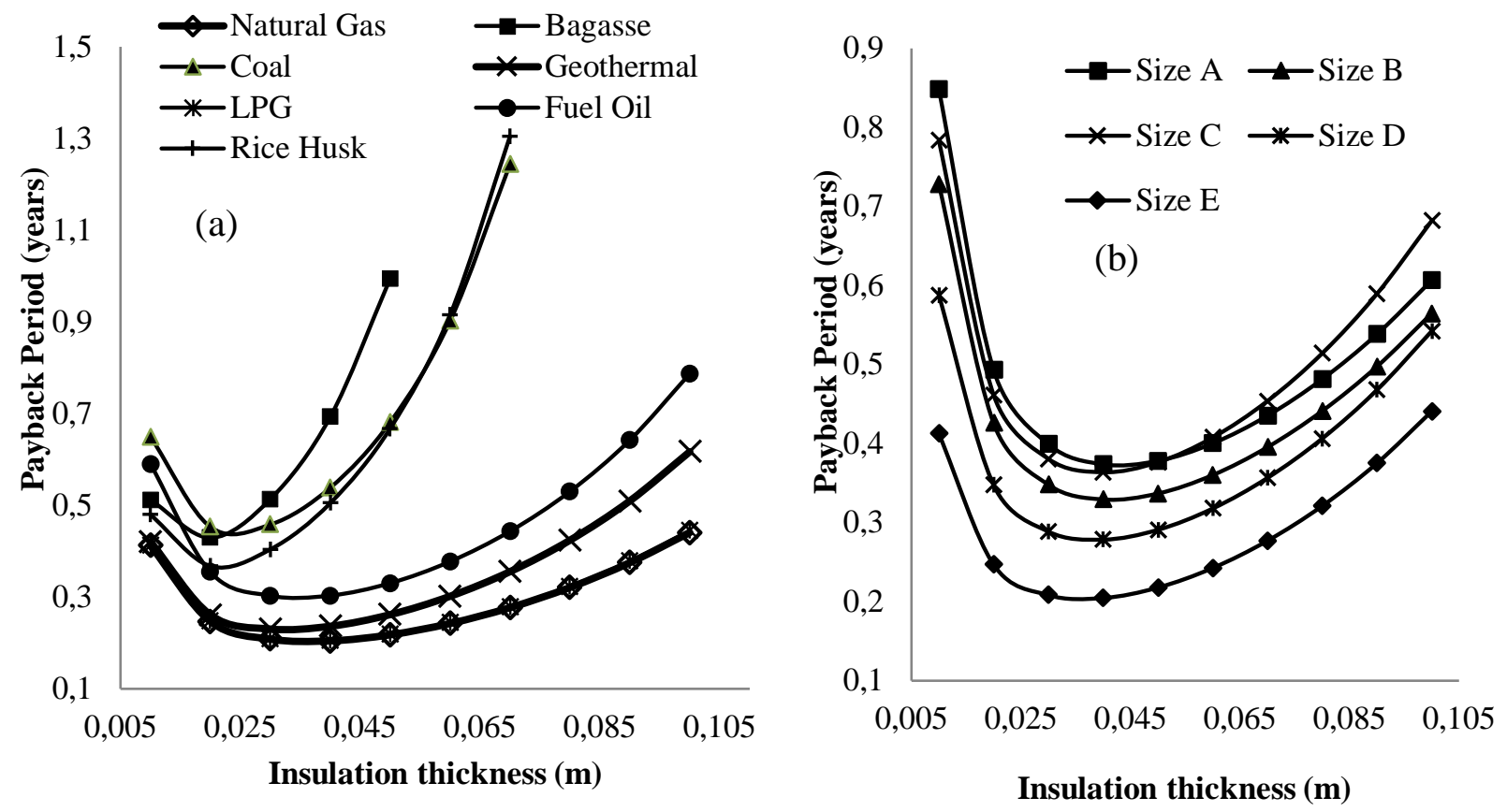

Figure 5. PP V/S insulation thickness for different (a) energy sources in size $\mathrm{E}$ and (b) sizes in case of NG

The use of insulation material on the HVAC duct reduces heat loss. Fig. 6a exhibits the effect of insulation thickness on the annual fuel consumption of different fuel types. Fuel consumption decreases with insulation thickness. Once OIT is achieved, further increasing insulation thickness insignificantly reduces fuel consumption. The results show that fuel consumption varies between $4.2-50.12 \mathrm{~kg} / \mathrm{m}$-year in the duct size $\mathrm{E}$ at different energy sources. The higher decrement in fuel consumption is determined in duct size $\mathrm{E}$ for bagasse, $\mathrm{RH}$ and coal, and its intermediate decrement is determined for FO whereas its lower decrement is determined for LPG, NG and geothermal. Moreover, the effect of insulation thickness on fuel consumption in different duct sizes is illustrated in Fig. $\mathbf{6 b}$ for NG as a fuel. The high fuel consumption decrement occurs in size A i.e. $19.52 \mathrm{~kg} / \mathrm{m}$-year and size $\mathrm{E}$ has lower value i.e. $6.26 \mathrm{~kg} / \mathrm{m}$ year corresponding to OIT. 
Journal of Thermal Engineering, Research Article, Vol. 6, No. 1, pp. 141-156, January, 2020

Table 4. OIT, ES and PP for different duct sizes at various fuel types

\begin{tabular}{|l|l|c|c|c|c|c|}
\hline \multirow{2}{*}{ Fuel Type } & \multicolumn{5}{|c|}{ Parts of air distribution system } \\
\cline { 2 - 7 } & & A & B & C & D & E \\
\hline \multirow{5}{*}{ OIT(mm) } & NG & 48.27 & 41.2 & 39.72 & 38.54 & 36.5 \\
\cline { 2 - 7 } & Bagasse & 16.93 & 16.92 & 16.35 & 16.91 & 17.29 \\
\cline { 2 - 7 } & Coal & 19.38 & 19.22 & 18.65 & 21.29 & 24.15 \\
\hline & Geothermal & 37.16 & 35.93 & 34.69 & 33.91 & 32.44 \\
\cline { 2 - 7 } & LPG & 42.7 & 41.08 & 39.57 & 38.4 & 36.38 \\
\cline { 2 - 7 } & FO & 30.67 & 29.77 & 28.79 & 30.31 & 34.64 \\
\cline { 2 - 7 } & RH & 21.32 & 21.09 & 21.29 & 20.69 & 20.7 \\
\hline ES(\%) & NG & 74.01 & 76.41 & 74.56 & 79.29 & 83.95 \\
\cline { 2 - 7 } & Bagasse & 50.24 & 54.63 & 52.06 & 60.9 & 70.49 \\
\cline { 2 - 7 } & Coal & 54.17 & 58.26 & 55.79 & 64.13 & 70.67 \\
\cline { 2 - 7 } & Geothermal & 71.03 & 73.63 & 71.67 & 76.97 & 82.27 \\
\cline { 2 - 7 } & LPG & 74.02 & 76.33 & 74.48 & 79.23 & 83.91 \\
\cline { 2 - 7 } & FO & 66.44 & 69.47 & 67.36 & 73.58 & 78.09 \\
\cline { 2 - 7 } & RH & 56.92 & 60.79 & 58.35 & 66.15 & 74.38 \\
\hline PP(years) & NG & 0.3727 & 0.3291 & 0.3638 & 0.2783 & 0.2035 \\
\hline & Bagasse & 1.005 & 0.8454 & 0.9436 & 0.657 & 0.4296 \\
\hline & Coal & 0.9081 & 0.768 & 0.8526 & 0.597 & 0.4531 \\
\hline & Geothermal & 0.4354 & 0.382 & 0.4218 & 0.3189 & 0.2295 \\
\hline & LPG & 0.3744 & 0.3305 & 0.3653 & 0.2793 & 0.2042 \\
\hline & FO & 0.5398 & 0.4691 & 0.5177 & 0.3829 & 0.299 \\
\hline & RH & 0.8112 & 0.6904 & 0.7636 & 0.5468 & 0.3674 \\
\hline
\end{tabular}

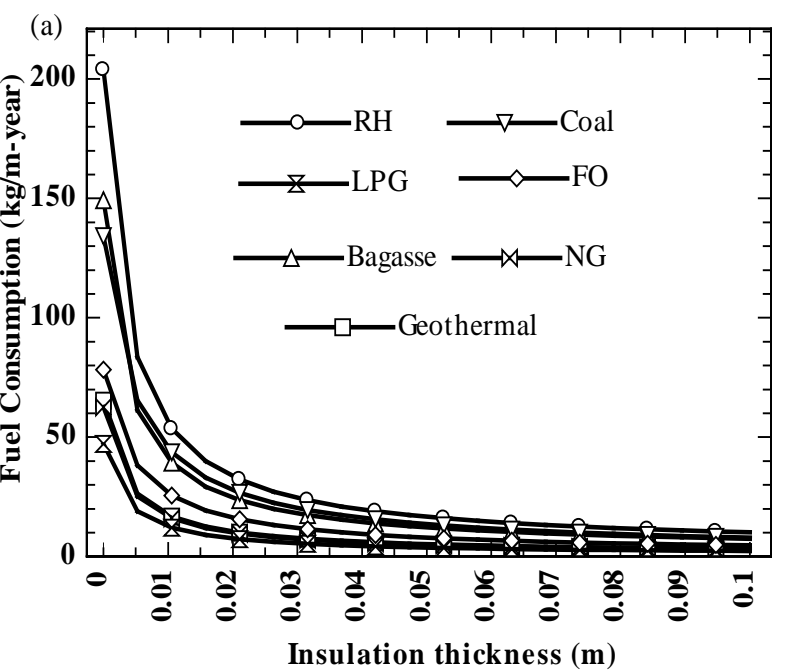

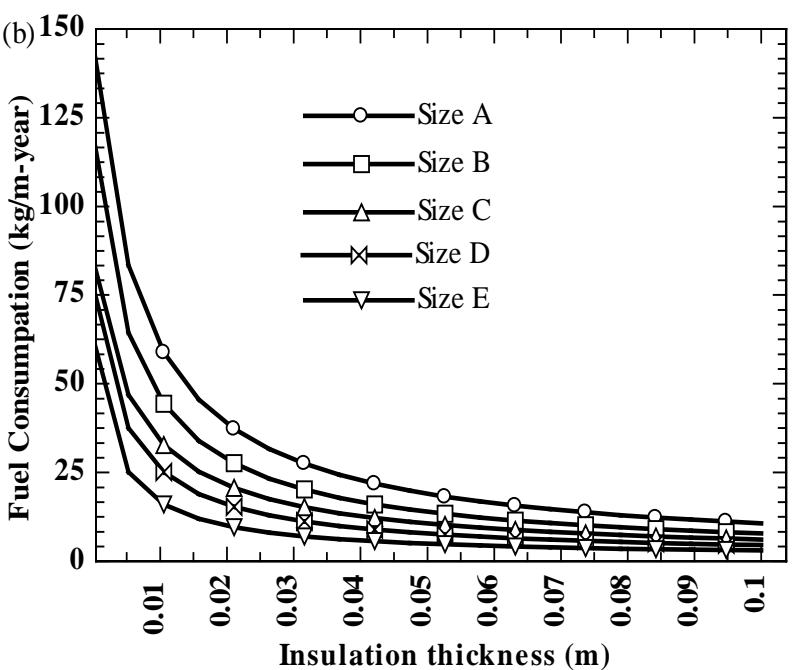

Figure 6. Fuel consumption V/S insulation thickness for different (a) energy sources in size E and (b) sizes in case of NG 

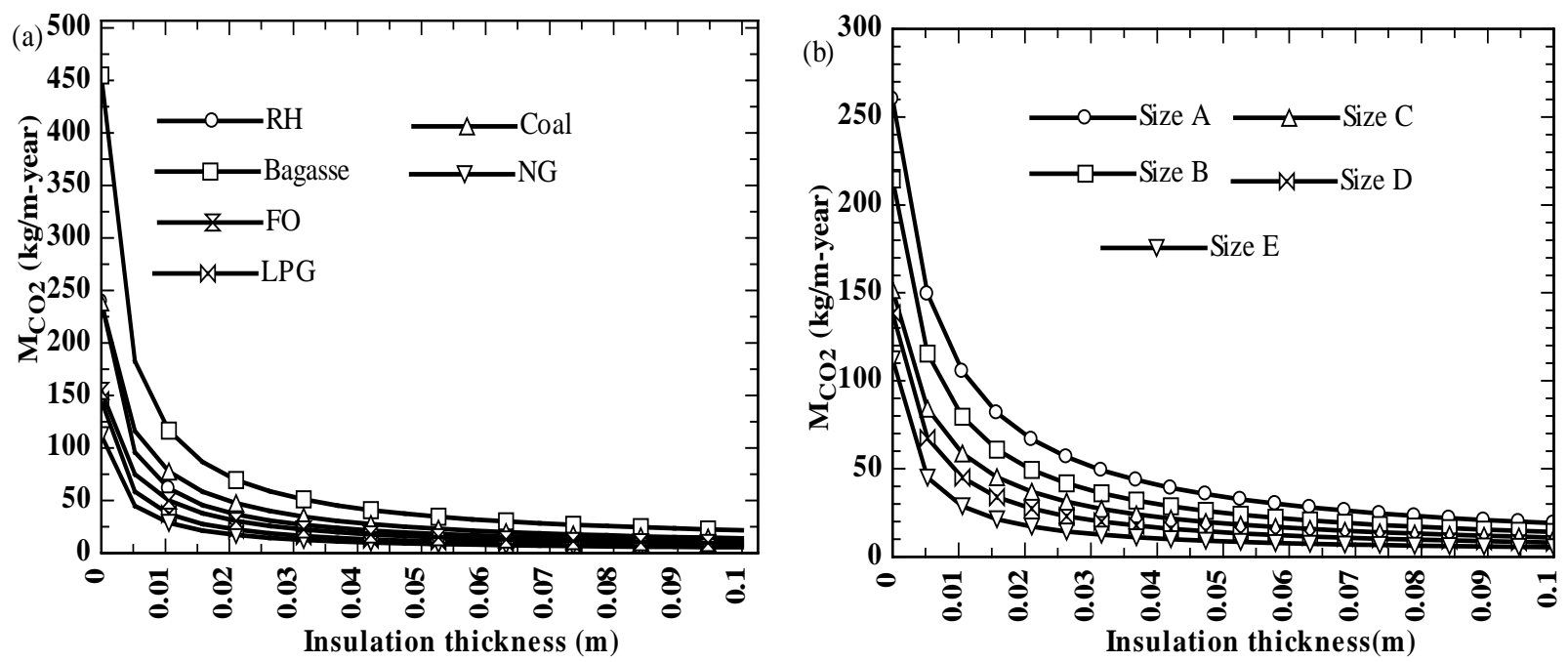

Figure 7. The annual $\mathrm{CO}_{2}$ emissions versus insulation thickness (a) for different energy sources in size $\mathrm{E}$ and (b) sizes in case of NG

Figure 7 (a and b) shows the variation in $\mathrm{CO}_{2}$ emission with insulation thickness for duct sizes and different energy sources. The use of insulation over the HVAC duct reduces fuel consumption of an HVAC system and resulting emission products. The $\mathrm{CO}_{2}$ emission decreases with insulation thickness. The higher value of $\mathrm{CO}_{2}$ emission corresponding to OIT is determined for size A and bagasse i.e. $192 \mathrm{~kg} / \mathrm{m}$-year, whereas its lower value for size $\mathrm{E}$ and NG i.e. $11.27 \mathrm{~kg} / \mathrm{m}$-year. The decrement in $\mathrm{CO}_{2}$ emission due to OIT for different duct sizes varies between 11.23$34.04 \mathrm{~kg} / \mathrm{m}$-year for NG, $81.81-318.33 \mathrm{~kg} / \mathrm{m}$-year for bagasse, $40.73-123.43 \mathrm{~kg} / \mathrm{m}$-year for coal, $14.57-50.14 \mathrm{~kg} / \mathrm{m}$-year for LPG, 20.38-56.39kg/m-year and 37.04-141.59kg/m-year for RH, respectively.
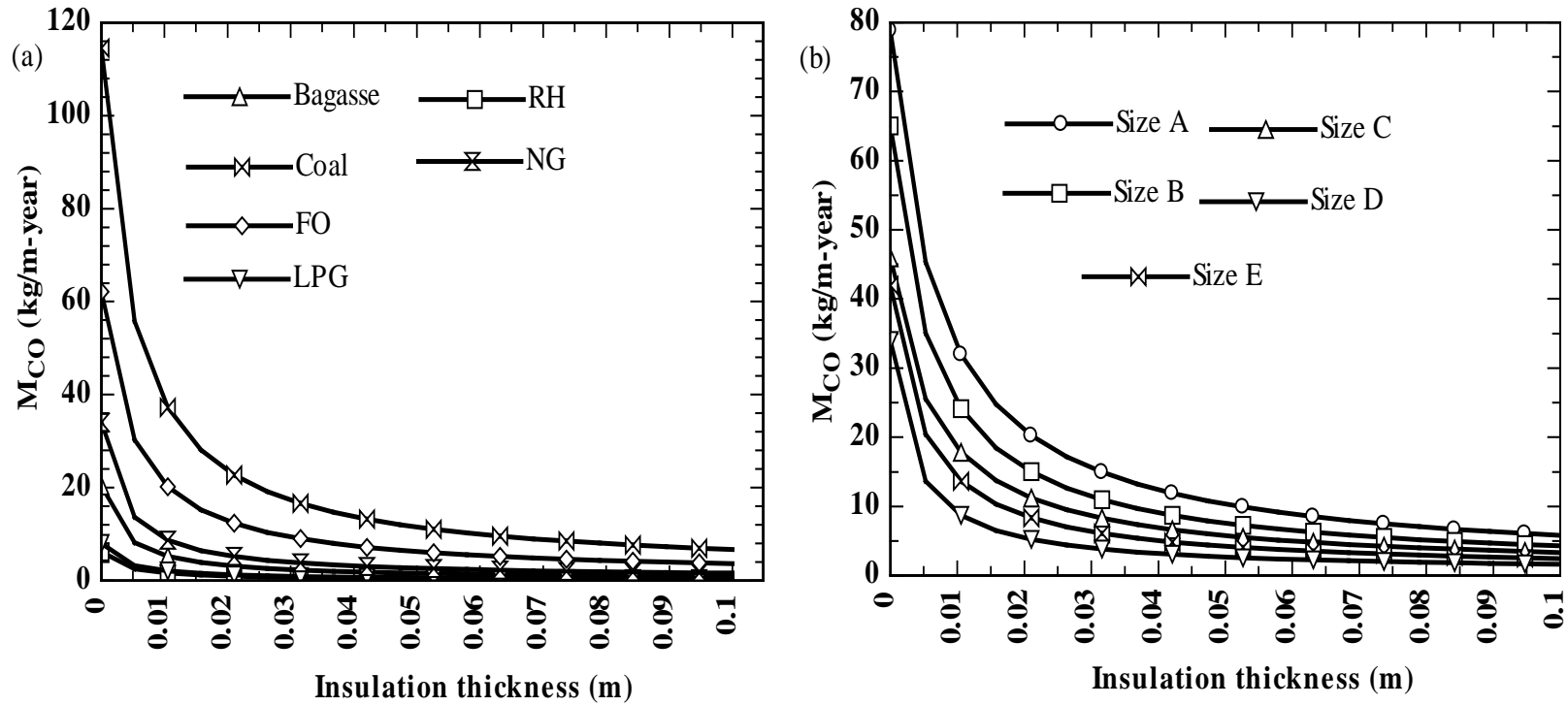

Figure 8. The CO emissions versus insulation thickness for different (a) energy sources in size E and (b) sizes in case of NG 

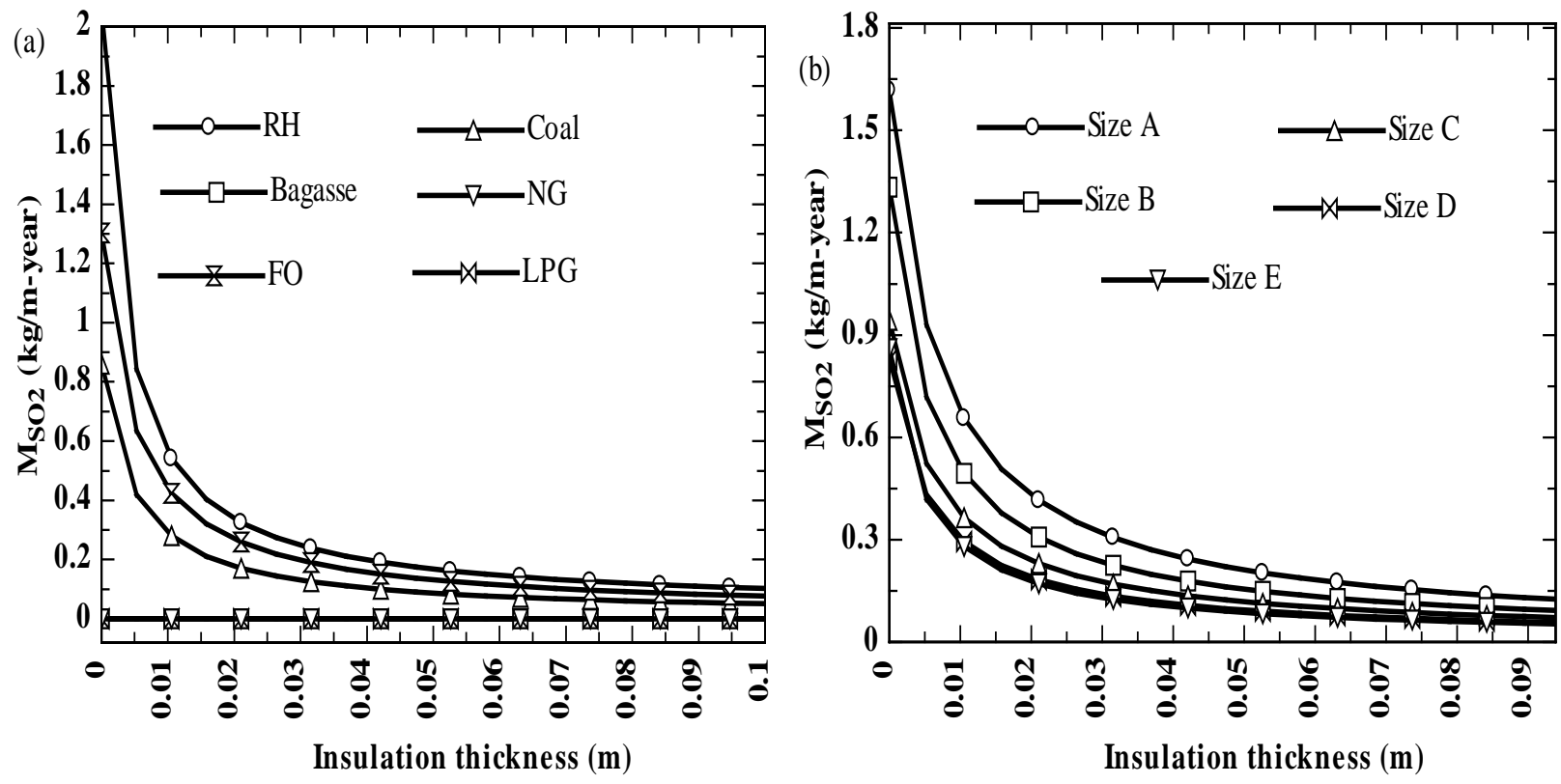

Figure 9. The SO2 emissions versus insulation thickness for different (a) energy sources in size E and (b) sizes in case of coal

Figures 8 and 9 exhibits the variation in $\mathrm{CO}$ and $\mathrm{SO}_{2}$ emission for different duct sizes with insulation thickness under different fuel types. The $\mathrm{CO}$ and $\mathrm{SO}_{2}$ emission decrease with insulation thickness and duct size. The $\mathrm{CO}$ and $\mathrm{SO}_{2}$ emission determined for size $\mathrm{A}$ is higher than size $\mathrm{E}$. The higher value of $\mathrm{CO}$ emission corresponding to OIT is determined for size A and coal i.e. $59.28 \mathrm{~kg} / \mathrm{m}$-year, whereas its lower value for size E and LPG i.e. $0.8 \mathrm{~kg} / \mathrm{m}$-year. The decrement in CO emission due to OIT for different duct sizes varies between 3.4-10.3kg/m-year for NG, 3.67$14.26 \mathrm{~kg} / \mathrm{m}$-year for bagasse, $19.56-59.28 \mathrm{~kg} / \mathrm{m}$-year for coal, $0.8-2.77 \mathrm{~kg} / \mathrm{m}$-year for LPG, $8.21-22.72 \mathrm{~kg} / \mathrm{m}$-year and $0.97-3.97 \mathrm{~kg} / \mathrm{m}$-year for $\mathrm{RH}$, respectively. Similarly, the higher value of $\mathrm{SO}_{2}$ emission corresponding to OIT is determined for size A and RH i.e. $0.99 \mathrm{~kg} / \mathrm{m}$-year, whereas it's lower value for size $\mathrm{E}$ and coal i.e. $0.15 \mathrm{~kg} / \mathrm{m}$-year. The decrement in $\mathrm{SO}_{2}$ emission due to OIT for different duct sizes varies between $0.15-0.45 \mathrm{~kg} / \mathrm{m}$-year for coal, 0.17$0.48 \mathrm{~kg} / \mathrm{m}$-year and $0.25-0.99 \mathrm{~kg} / \mathrm{m}$-year for $\mathrm{RH}$, respectively.

The percentage of fuel savings with OIT in different duct sizes is illustrated in Fig. 10. The highest value of percentage of fuel consumption reduced with OIT in different duct sizes is varying in between $36.87-40.90 \%$ in case of NG, 25.89-33.87\% in case of bagasse, $28.45-33.87 \%$ in case of coal, 35.56-40.09\% in case of geothermal, 36.84$40.88 \%$ in case of LPG, 32.72-38.33\% in case FO, $27.58-33.74 \%$ in case of RH and the total amount of fuel consumption saved is varying in between 29.24-35.98\% considering all types of fuel.

The percentage of emission reduction due to OIT for different parts of the air distribution system using various fuels is illustrated in Figure 11. The highest percentage of $\mathrm{CO}_{2}$ emission reduced with OIT in different parts of air distribution system is varying in between $37.74-81.1 \%$ in case of NG, 53.64-69.5\% in case of bagasse, 56.84-70.81\% in case of coal, 73.68-81.78\% in case of LPG, $67.44-76.66 \%$ in case fuel oil, 59.36-73.2\% in case of RH and the total amount of $\mathrm{CO}_{2}$ emission reduced is varying in between $58.48-71.96 \%$ considering all types of fuel. Similarly, the percentage of $\mathrm{CO}, \mathrm{SO}_{2}$ emission reduction is estimated. 


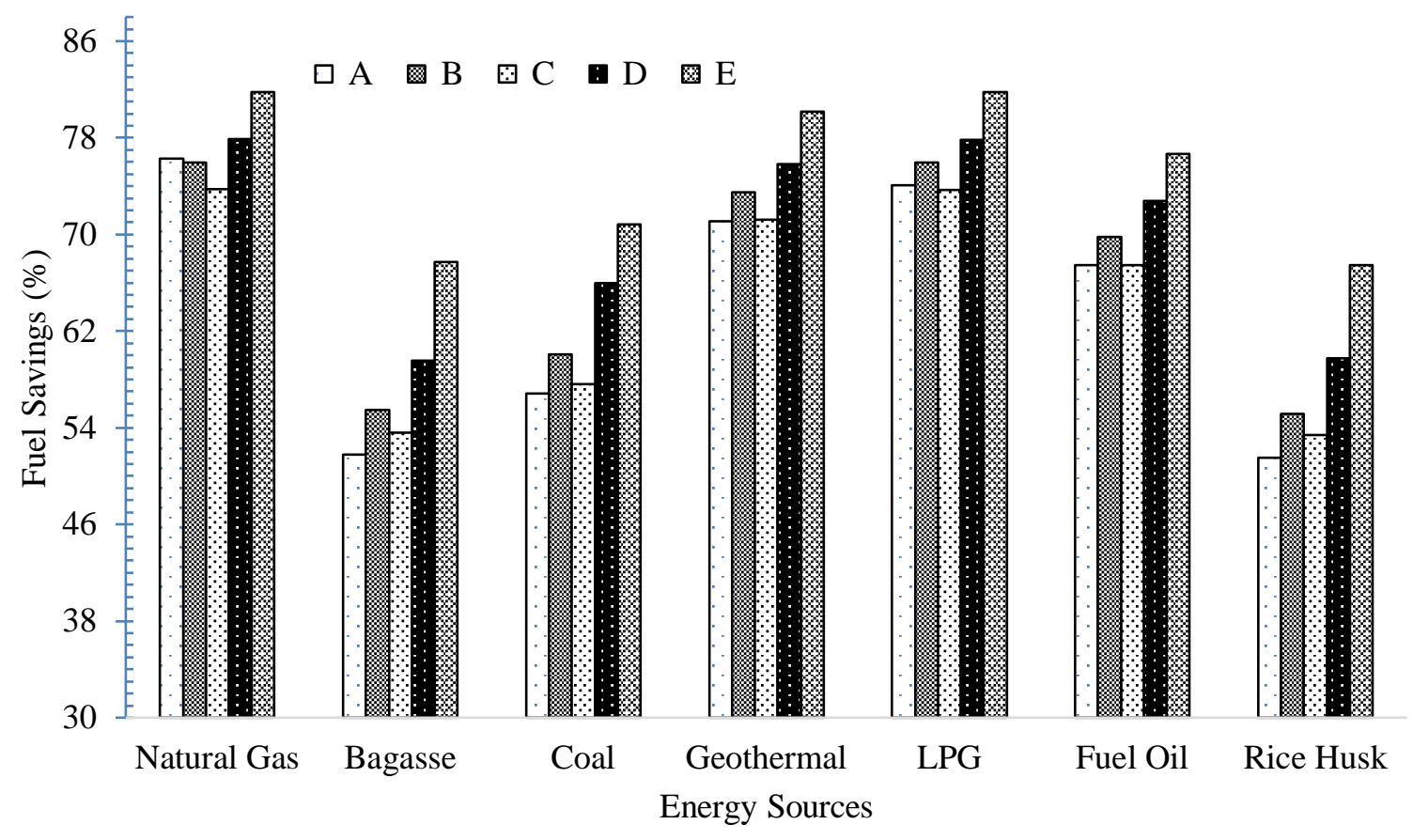

Figure 10. Annual percentage of fuel reduction in different parts of the air distribution system

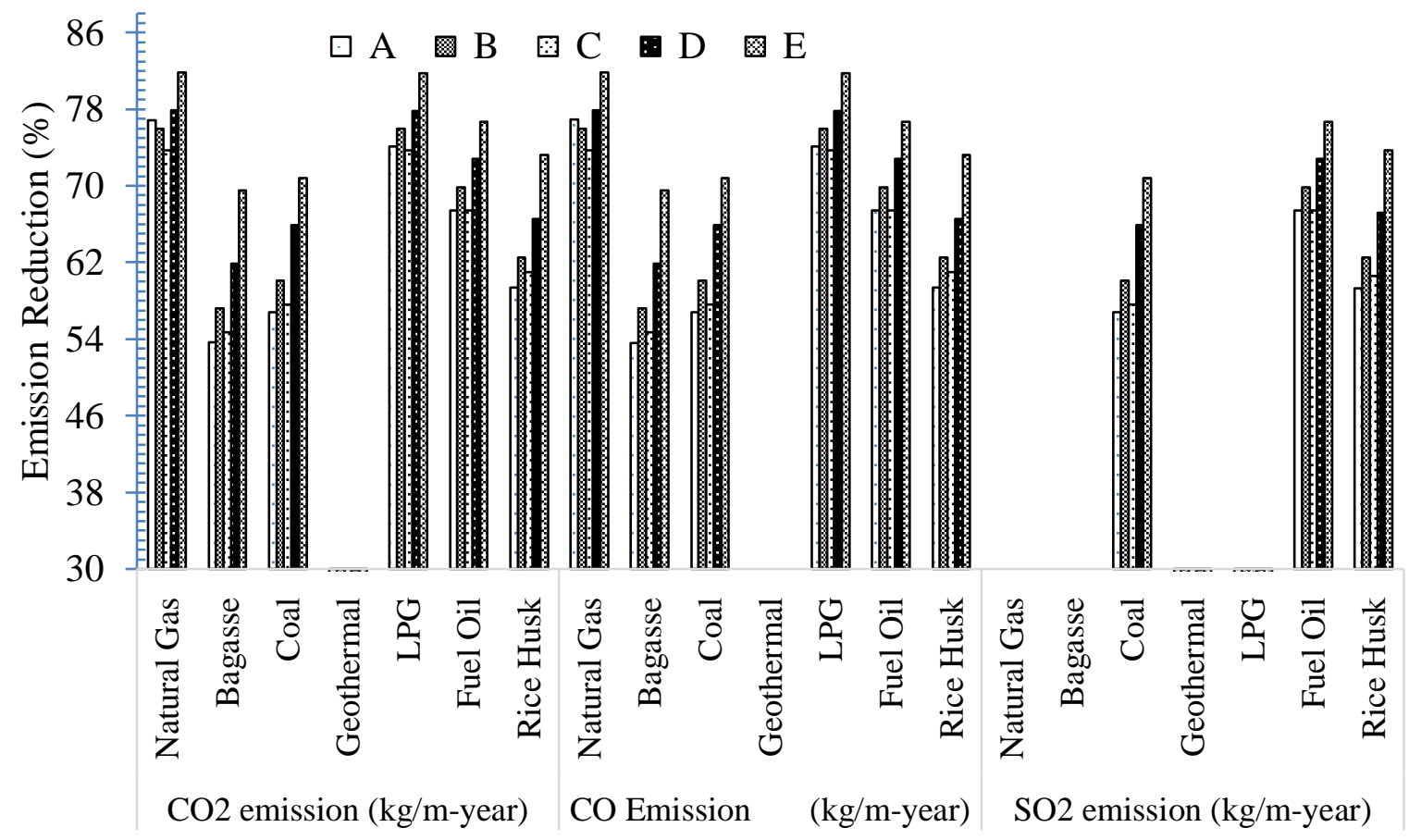

Figure 11. Percentage of emission reduction versus different fuel use in air distribution system HVAC system Note: Duct size A 300 mm, B 350 mm, C 400 mm, D 450 mm \& E 500 mm. 


\section{CONCLUSION}

In this study, the effect of energy source and HVAC's duct size on OIT, ES, PP are estimated using LCC analysis. This study also investigates the environmental impacts of insulation thickness on different duct sizes of an air distribution system installed outside the building in a pharmaceutical company, in the city Jamshoro, Pakistan. In this analysis, NG, LPG, coal, FO, bagasse, RH and geothermal are considered as energy sources and fiberglass as an insulation material. On the basis of the obtained results, the following conclusion is made from the present study:

The OIT decreases with the duct size for various energy sources.

The higher value of OIT is obtained for duct size A and NG i.e. $48.27 \mathrm{~mm}$ and it's lower value for duct size E and bagasse i.e. $17.40 \mathrm{~mm}$.

The ES values decrease with duct size. The highest value of the ES is estimated for size E and NG i.e. 83.95 whereas its lower value is obtained for Part A and bagasse i.e. 50.24\%, respectively.

The PP increases with the duct size. The longer value of PP is estimated for part A and bagasse i.e. 1.005year and its smallest value are 0.204year for size $\mathrm{E}$ and NG.

The annual fuel consumption, $\mathrm{CO}_{2}, \mathrm{CO}$ and $\mathrm{SO}_{2}$ emission decrease with insulation thickness. The maximum percentage reduction in fuel consumption corresponding to OIT is around $81.8 \%$ for size A and NG and lower reduction is 51.78 for size $\mathrm{E}$ and bagasse, respectively.

The emission of $\mathrm{CO}_{2}$, $\mathrm{CO}$ and $\mathrm{SO}_{2}$ vary between $53.64-81.8 \%$, 53.62-81.76\% and $49.64-76.66 \%$ for different parts and energy sources, respectively.

Considering environmental impacts geothermal as an energy source is a better choice.

Considering economic and environmental impacts bagasse as an energy source is a better choice.

\section{NOMENCLATURE}

A

$D$

$d$

$h$

i

K

$L$

$\dot{m}$

$N$

$\mathrm{Nu}$

$\mathrm{Pr}$

$\dot{Q}$

Re

$r$

$R$

$U$

V

$t$

$\vartheta$

$f$

$\varepsilon$

$\beta$

$f$

$h$

i

ins

o

$T$

EC

EES
Duct's external surface area, $\mathrm{m}^{2}$

Diameter of the duct, $\mathrm{m}$

inflation rate, \%

Convective heat transfer co-efficient, $\mathrm{W} / \mathrm{m}^{2}{ }^{\circ} \mathrm{C}$

interest rate, \%

Thermal conductivity, $\mathrm{W} / \mathrm{m}{ }^{\circ} \mathrm{C}$

Length of the Duct, $\mathrm{m}$

Mass Flow Rate, kg/s

Life time, year

Nusselt Number

Prandtl Number

Heat gain, $\mathrm{W}$

Reynolds Number

Radius,

Thermal resistance, ${ }^{\circ} \mathrm{C} / \mathrm{W}$

Velocity, $\mathrm{m} / \mathrm{s}$

Volume Flow Rate $\left(\mathrm{m}^{3} / \mathrm{s}\right)$

thickness, $\mathrm{m}$

Kinematic viscosity (m2/s)

friction factor (-)

relative roughness (-)

Excess air

Fuel

hydraulic

inlet

insulation

outside

Total

Energy Consumption

Engineering Equation Solver 
Journal of Thermal Engineering, Research Article, Vol. 6, No. 1, pp. 141-156, January, 2020

ES

LCC Life cycle cost

OIT Optimum insulation thickness

PP Payback Period

\section{REFERENCES}

[1] Holdren JP. Population and the Energy Problem. Population and Environment: A Journal of Interdisciplinary Studies. 1991;12:231-155.

[2] Kumar D, Memon RA, Memon AG, Tunio IA, Junejo A. Impact of Auxiliary Equipments' Consumption on Electricity Generation Cost in Selected Power Plants of Pakistan. Mehran University Research Journal of Engineering \& Technology, 2017;36(2):419-36.

[3] Mohsen MS, Akash BA. Some Prospects of Energy Savings in Building. Energy conversion and management. 2001;42:1307-15

[4] Pe'rez-Lombard L, Ortiz J, Pout C. A review on buildings energy consumption information. Energy and Buildings 200840 394-8.

[5] Shaikh PH, Nor NBM, Nallagownden P, Elamvazuthi I, Ibrahim T. A review on optimized control systems for building energy and comfort management of smart sustainable buildings. Renewable and Sustainable Energy Reviews. 2014;34:409-29.

[6] Sahin AZ, Kalyon M. Maintaining uniform surface temperature along pipes by insulation. Energy 2005;30:63747.

[7] Kaynakli O. Economic thermal insulation thickness for pipes and ducts: A review study. Renewable and Sustainable Energy Reviews 2014;30:184-94.

[8] Zaki GM, Al-Turki AM. Optimization of Multilayer Thermal Insulation for Pipelines. Heat Transfer Engineering. 2000;21:63-70.

[9] Li YF, Chow WK. Optimum insulation-thickness for thermal and freezing protection Applied Energy 2005;80:23-33.

[10] Soponpongpipat N, Jaruyanon P, Nanetoe S. The Thermo-Economics Analysis of the Optimum Thickness of Double-Layer Insulation for Air Conditioning Duct. Energy Research Journal 2010;1(2):146-51.

[11] Keçebas A, Kayfeci M, Gedik E. Performance investigation of the Afyon geothermal district heating system for building applications: Exergy analysis. Applied Thermal Engineering 2011;31:1229-37.

[12] Keçebas A. Performance and thermo-economic assessments of geothermal district heating system: A case study in Afyon, Turkey. Renewable Energy. 2011;36:77-83.

[13] Yildiz A, Ersöz MA. The effect of wind speed on the economical optimum insulation thickness for HVAC duct applications. Renewable and Sustainable Energy Reviews. 2016;55:1289-300.

[14] Comaklı K, Yuksel B. Environmental impact of thermal insulation thickness in buildings. Applied Thermal Engineering. 2004;24:933-40.

[15] Dombayc1 OA. The environmental impact of optimum insulation thickness for external walls of buildings. Building and Environment. 2007;42:3855-9.

[16] Yildiz A, Gürlek G, Erkek M, Özbalta N. Economical and environmental analyses of thermal insulation thickness in buildings. Journal of Thermal Science and Technology. 2008;28(2):25-34.

[17] Basogul Y, Keçebas A. Economic and environmental impacts of insulation in district heating pipelines. Energy 2011;36:6156-64.

[18] Abdallah AM, Krameldin A. Optimum Thermal Design of Steam Pipelines and its Impact on Environment Pollution. HEB; Cairo, Egypt, 1999. p. 57-74.

[19] Kumar D, Memon AG, Memon RA, Ali I, Nord N. Parametric study of condensation at heating, ventilation, and air-conditioning duct's external surface. Building Services Engineering Research and Technology. 2018;39(3):328-42.

[20] Baloch MH, Kaloi GS, Memon ZA. Current scenario of the wind energy in Pakistan challenges and future perspectives: A case study. Energy Reports. 2016;2:201-10.

[21] Kumar D, Memon RA, Memon AG. Energy Analysis of selected air distribution system of Heating, Ventilation and Air conditioning system: A case study of pharmaceutical company. Mehran University Research Journal of Engineering \& Technology. 2017;36(3):746-56.

[22] Memon AG, Memon RA. Parametric based economic analysis of a trigeneration system proposed for residential buildings. Sustainable Cities and Society. 2017;34:144-58. 
[23] Keçebas A, Alkan MA, Bayhan M. Thermo-economic analysis of pipe insulation for district heating piping systems. Applied Thermal Engineering. 2011;31:3929-37.

[24] Barzegarian R, Moraveji MK, Aloueyan A. Experimental investigation on heat transfer characteristics and pressure drop of BPHE (brazed plate heat exchanger) using TiO 2 -water nanofluid. Experimental Thermal and Fluid Science. 2016;74:11-8.

[25] Cengel YA. Heat Transfer: A Practical Approach. 2 ed. USA: McGraw-Hill; 2003.

[26] Holman JP. Heat Transfer 10 ed. NewYork, Americas: McGraw-Hill; 2010.

[27] Kumar D, Memon RA, Memon AG, Ali I, Junejo A. Critical analysis of the condensation of water vapor at external surface of the duct. Heat and Mass Transfer. 2018;54:1937-50.

[28] Kim M, Kim D, Esfahani IJ, Lee S, Kim M, Yoo C. Performance assessment and system optimization of a combined cycle power plant (CCPP) based on exergoeconomic and exergoenvironmental analyses. Korean Journal of Chemical Engineering. 2016;34(1):6-19.

[29] Oil and Gas Regulatory Authority. 2016. Available: http://www.ogra.org.pk/ [assessed on 09.03.2017]

[30] Repoter S. Coal prices rise to \$81/ton, Dawn Newspaper, Pakistan. 2016. [assessed on 09.03.2017].

[31] Pakistan Sugar Mills Association: Chairman's Annual Review (2016). Available: http://www.psmacentre.com/aboutus.php?id=6\&type=annual_review\&status=1 [assessed on 09.03.2017].

[32] Suramaythangkoor T, Gheewala SH. Potential alternatives of heat and power technology application using rice straw in Thailand. Applied Energy 2010;87:128-33.

[33] Munir A, Tahir AR, Sabir MS, Ejaz K. Efficiency calculations of bagasse fired boiler on the basis of flue gases temperature and total heat values of steam. Pak J Life Soc Sci. 2004;2:36-9.

[34] Ali ZM, Tunio MM, Laghari AJ, Laghari AQ. Cogeneration Technology: Cleaner and Environment Friendly. Quaid-E-Awam University Research Journal of Engineering, Science \& Technology. 2016;14:54-6.

[35] Lori JA, Lawal AO, Ekanem EJ. Proximate and Ultimate Analyses of Bagasse, Sorghum and Millet Straws as Precursors for active carbons. Journal of Aplied Sciences. 2007;7(21):3249-55.

[36] Yadav J, Singh BR. Study on Comparison of Boiler Efficiency Using Husk and Coal as Fuel in Rice Mill. Samriddhi-JPSET. 2011;2(2):1-15.

[37] Efomah AN, Gbabo A. The physical, proximate and ultimate analysis of rice husk briquettes produced from a vibratory block mould briquetting machine. IJISET - International Journal of Innovative Science, Engineering \& Technology. 2015;2(5):814-22.

[38] Abbas T, Ahmed Bazmi A, Waheed Bhutto A, Zahedi G. Greener energy: Issues and challenges for Pakistangeothermal energy prospective. Renewable and Sustainable Energy Reviews. 2014;31:258-69.

[39] Munir A, Alvi JZ, Ashfaq S, Ghafoor A. Performance evaluation of a biomass boiler on the basis of heat loss method and total heat values of steam. Pakistan Journal of Agricultural Sciences 2014;51:209-15.

[40] Memon AG, Memon RA, Harijan K, Uqaili MA. Parametric based thermo-environmental and exergoeconomic analyses of a combined cycle power plant with regression analysis and optimization. Energy Conversion and Management. 2015;92:19-35. 